\title{
PERAN AGEN PERUBAHAN DALAM PENGEMBANGAN MASYARAKAT LOKAL YANG BERKELANJUTAN
}

\author{
Aldim \\ UIN Sunan Gunung Djati Bandung \\ Email: aldim8462@gmail.com
}

\begin{abstract}
Abstrak
Artikel ini membahas tentang pentingnya modal sosial sebagai indikator utama kemampuan masyarakat untuk terlibat dalam pembangunan berkelanjutan, karena modal sosial dapat memiliki efek menghambat dan memfasilitasi. Agen perubahan diharapkan dapat memungkinkan individu atau kelompok untuk meningkatkan akses ke bentuk modal kritis lainnya untuk mengatasi hambatan dan menyelesaikan masalah. Modal sosial terikat terdiri dari ikatan jaringan yang kuat sebagai negatif dalam jumlah berlebih karena dapat mengarah pada penegakan norma-norma sosial yang menghambat perubahan inovatif, dan modal sosial penghubung yang terdiri dari ikatan jaringan yang lemah sebagai manfaat yang memungkinkan para pelaku untuk melakukan perubahan sosial yang kritis. Masyarakat mencapai perubahan melalui campuran dinamis ikatan yang terikat dan ikatan penghubung.
\end{abstract}

Kata Kunci: Agen Perubahan, Modal Sosial, Ikatan Terikat, Ikatan Penghubung.

\begin{abstract}
This article discusses the importance of social capital as a key indicator of people's ability to engage in sustainable development, because social capital can have a deterring and facilitating effect. Change agents are expected to enable individuals or groups to increase access to other forms of critical capital to overcome obstacles and solve problems. Bonded social capital consists of strong network ties as negative in excess of numbers because it can lead to the enforcement of social norms that inhibit innovative change, and connecting social capital consisting of weak network ties as a benefit that allows actors to make social changes that are critical. Society achieves change through a dynamic mix of bonding and connecting bonds.
\end{abstract}

Keywords: Agent of Change, Social Capital, Bonded Bonds, Liaison Bonds.

\section{A. PENDAHULUAN}

Ketika tekanan ekologis meningkat, pembangunan berkelanjutan, didefinisikan oleh Komisi Brundtland (1987), sebagai 'memenuhi kebutuhan saat ini tanpa mengurangi kemampuan generasi masa depan untuk memenuhi kebutuhan mereka sendiri dan terus memainkan peran yang semakin meningkat dalam perencanaan di semua tingkatan organisasi sosial. Meskipun pemerintah internasional dan nasional memiliki peran penting dalam memainkan implementasi pembangunan berkelanjutan, banyak gerakan praktis menuju pembangunan berkelanjutan terjadi di tingkat masyarakat. Banyak masyarakat berusaha 
untuk menyelesaikan konflik di sekitar berbagai penggunaan lahan, di mana nilai-nilai sering dipegang erat dan pemangku kepentingan berbeda pada jenis dan skala pembangunan.

Berbeda dengan respons hierarkis terstruktur dari badan-badan nasional dan internasional, prakarsa pembangunan berkelanjutan masyarakat cenderung lebih bersifat organik, karena kelompok warga yang peduli mengorganisir diri di sekitar isu-isu spesifik dan mencoba menyelesaikan konflik sumber daya yang saling bersaing. Mengingat kompleksitas masalah pembangunan berkelanjutan, masyarakat sering merasa kesulitan untuk terlibat secara memadai dengan masalah yang ada, serta dengan pemangku kepentingan. Seringkali masalah berada di luar kemampuan komunitas mana pun untuk menyelesaikannya, dan implementasi serta pemantauan solusi dapat menyaring sumber daya masyarakat (Dale, 2004).

Pembangunan berkelanjutan dapat dianggap sebagai proses rekonsiliasi tiga keharusan yaitu: (i) keharusan ekologis untuk hidup dalam daya dukung biofisik global dan menjaga keanekaragaman hayati; (ii) keharusan sosial untuk memastikan pengembangan sistem pemerintahan yang demokratis untuk secara efektif menyebarkan dan mempertahankan nilai-nilai yang ingin dijalani oleh masyarakat; dan (iii) keharusan ekonomi untuk memastikan bahwa kebutuhan dasar dipenuhi di seluruh dunia (Robinson \& Tinker, 1997; Dale, 2001). Inisiatif pembangunan berkelanjutan masyarakat harus merekonsiliasi ketiga keharusan untuk mencapai pengambilan keputusan yang terintegrasi.

Banyak komunitas mengatasi masalah kompleks ini dengan membentuk jaringan. Jaringan adalah sarana yang kuat untuk mendistribusikan pengetahuan dan dapat mengarah pada rekonsiliasi informasi, kepentingan, dan agenda yang sebelumnya bersaing (Dale \& Onyx, 2005).

Sebuah jaringan terdiri dari pelaku-pelaku yang terhubung oleh ikatan dan ikatan yang berbeda menciptakan jaringan yang berbeda (Borgatti \& Foster, 2003). Banyak peneliti menyebut jaringan seperti modal sosial, seperti yang akan dibahas secara rinci di bawah ini. Para peneliti menyarankan bahwa peningkatan jumlah modal sosial yang tersedia yang dibentuk dengan meningkatkan ukuran dan kepadatan jaringan akan memiliki efek positif pada komunitas.

Namun meskipun jaringan pribadi memberikan solusi untuk masalah yang disebabkan oleh sistem (Volker \& Flap, 2001), tidak semua koneksi dalam jaringan sama. Jaringanjaringan pelaku sering terfokus di sekitar kelompok inti yang terhubung erat (McPherson et al., 1999), tetapi beberapa peneliti mengakui hubungan di tepi kelompok inti sangat penting 
untuk keberlanjutan jangka panjang jaringan. Di tepi kelompok inti kita menemukan 'ikatan lemah' yang terhubung ke berbagai kelompok (Granovetter, 1973). Granovetter (1973) mengemukakan bahwa ikatan lemah melakukan fungsi khusus dalam jaringan. Dia menyebut ikatan ini 'penghubung' karena mereka adalah satu-satunya jalan antara dua aktor yang terpisah, atau dua jaringan. Sampai karya Granovetter, para peneliti berasumsi bahwa ikatan 'kuat' inti inti dari suatu jaringan memainkan peran penting dalam menciptakan jaringan yang efektif, tetapi Granovetter berpendapat bahwa karena tidak ada ikatan yang terikat dapat menjadi penghubung; itu adalah ikatan penghubung yang menghubungkan jaringan ke dunia luar dan ke sumber daya dan informasi yang dibutuhkan yang tidak tersedia dalam kelompok lokal atau ke komunitas lokal.

\section{B. TINJAUAN PUSTAKA}

\section{Modal Sosial}

Salah satu definisi modal sosial adalah kombinasi ikatan yang terikat dan ikatan penghubung yang ditemukan dalam jaringan aktor. Modal sosial adalah area pertumbuhan terbesar dalam penelitian jaringan (Borgatti \& Foster, 2003). Konsep modal sosial berasal dari penekanan Durkheim pada kehidupan kelompok (Portes, 1998), tetapi baru-baru ini memperoleh definisi yang lebih formal sebagai sebuah konsep.

Ada beberapa definisi modal sosial. Bourdieu (1986), mendefinisikan modal sosial sebagai agregat dari sumber daya aktual atau potensial yang terkait dengan kepemilikan jaringan yang tahan lama dari lebih banyak hubungan yang kurang dilembagakan dari pengenalan timbal balik atau pengakuan. Lebih lanjut, ia berpendapat bahwa jejaring sosial tidak diberikan secara alami dan harus dibangun melalui strategi investasi yang berorientasi pada pelembagaan hubungan kelompok (Portes, 1998). Robert Putnam mendefinisikan modal sosial sebagai jejaring sosial dan norma timbal balik dan kepercayaan yang muncul dari mereka (Putnam, 2000).

Portes menggambarkan modal sosial sebagai kemampuan aktor untuk mendapatkan manfaat berdasarkan keanggotaan dalam jejaring sosial atau struktur lain (Portes, 1998). Onyx dan Bullen mengklaim modal sosial terdiri dari jaringan, timbal balik, kepercayaan, norma sosial, milik bersama dan agen sosial (Onyx \& Bullen, 2000).

Mengikuti jejak Granovetter dan teori jaringan, beberapa ahli teori membuat perbedaan antara keterikatan dan penghubung modal sosial (Narayan, 1999; Putnum, 2000; Woolcock, 2001; Leonard \& Onyx, 2004). Modal sosial terikat mengacu pada jejaring sosial 
yang memperkuat identitas eksklusif dan kelompok-kelompok yang homogen. Modal sosial ini muncul dari kontak pribadi yang berulang dan berkelanjutan, seperti yang terkait dengan interaksi keluarga, atau kelompok agama. Modal sosial penghubung melibatkan 'ikatan lemah' dengan kelompok lain yang dicatat oleh Granovetter. Modal sosial semacam itu dapat 'menghubungkan' orang di berbagai belahan sosial (Putnum, 2000\}.

Hanya ada sedikit studi terperinci tentang bagaimana modal sosial bekerja secara aktual; beberapa berpendapat bahwa modal sosial bekerja dengan mengatasi masalah tindakan kolektif dan mengurangi biaya transaksi sosial (Ryden \& Holman, 2004), yang lain merasa modal sosial menjembatani 'lubang struktural' dalam masyarakat (Borgatti \& Foster, 2003). Meskipun kurangnya detail tentang bagaimana melakukannya, ada perasaan intuitif umum bahwa modal sosial memperkuat komunitas dan khususnya yang merupakan unsur yang diperlukan untuk pengembangan masyarakat yang berkelanjutan (Dale \& Onyx, 2005). Beberapa berpendapat bahwa modal sosial adalah barang yang dapat memberi keseimbangan dalam mendukung lebih banyak tindakan (Fukuyama, 1999), dan bahwa modal sosial menciptakan kemakmuran ekonomi lokal, menjawab 'tragedi bersama' dan sangat penting untuk mempertahankan barang publik (Wilson, 1997).

Beberapa peneliti percaya pandangan saat ini tentang modal sosial mungkin terlalu positif; Portes (1998) merasa modal sosial telah menjadi 'obat semua' untuk penyakit yang mempengaruhi masyarakat di dalam dan luar negeri, dan bisa kehilangan nilai heuristiknya. Modal sosial hampir selalu dipandang sebagai positif, tetapi studi tentang manfaatnya masih berlangsung (Fine, 1999). Fine mengklaim 'Ada belum tentu sesuatu yang positif atau ditentukan sebelumnya tentang dampak modal sosial '(Fine, 1999).

\section{Efek Negatif Modal Sosial}

Konsep modal sosial menarik bagi para ahli teori pembangunan. Modal sosial populer karena berfokus pada aspek-aspek positif dari sosialisasi sambil mengesampingkan fitur yang kurang menarik (Portes, 1998). Kelemahan dari sudut pandang ini adalah ia mengasumsikan niat jinak; misalnya, Onyx dan Bullen (2000) menyatakan bahwa norma-norma sosial memberikan bentuk kontrol sosial informal, dan bahwa proses ini baik untuk masyarakat. Kami mempertanyakan asumsi terakhir ini.

Dalam jaringan komunitas, tindakan kreatif adalah hasil dari kemampuan aktor untuk mengumpulkan informasi yang tidak berlebihan dari jaringan mereka dan menghindari tekanan untuk menyesuaikan diri (Reuf, 2002). Kapasitas ini sangat penting untuk isu-isu 
pembangunan berkelanjutan yang menuntut cara-cara baru dalam melakukan bisnis, cara-cara baru dalam mengatur dan cara-cara baru dalam membuat keputusan sehari-hari, yang membutuhkan inovasi yang belum pernah terjadi sebelumnya. Sifat modal sosial sekarang akan mempengaruhi hasil dari kedua tujuan ini. Seringkali, struktur dan dinamika kelompok dari suatu jaringan akan memfasilitasi atau membatasi kemampuan untuk mengumpulkan informasi dan berinovasi. Beberapa peneliti berkomentar tentang ini; ikatan sosial dapat memenjarakan aktor dalam situasi maladaptif atau memfasilitasi perilaku yang tidak diinginkan (Borgatti \& Foster, 2003). Struktur jaringan seseorang mempengaruhi kemampuan seseorang untuk beradaptasi dengan perubahan signifikan dalam lingkungan (Gargiulo \& Benassi, 2000). Pendapat jaringan sekitarnya adalah sentral untuk keberangkatan awal dari konvensi selama inovasi (Reuf, 2002). Singkatnya, struktur sosial memungkinkan dan membatasi (Reuf, 2002).

Portes menyoroti empat potensi negatif dari modal sosial; modal sosial dalam bentuk jaringan yang sangat maju dapat mengarah pada pengucilan orang luar, klaim berlebihan pada anggota kelompok, pembatasan kebebasan individu dan penurunan level norma (Portes, 1998). Seperti yang akan kita bahas di bagian selanjutnya, ada bukti eksperimental untuk mendukung keberadaan efek negatif modal sosial ini. Ini menciptakan teka-teki bagi para peneliti yang bekerja di tingkat masyarakat.

Karena individu sendiri sering tidak memiliki sumber daya untuk membuat perubahan yang diperlukan, beberapa bentuk modal sosial masyarakat harus bermanfaat. Tetapi apa yang menjadikan modal sosial menjadi modal sosial yang baik? Bagi mereka yang mencoba membangun modal sosial, sebuah proses yang membutuhkan waktu dan upaya, bagaimana kita bisa tahu apakah modal sosial yang dibangun adalah bantuan atau hambatan?

Kami percaya bahwa dua jenis modal sosial yang berbeda bertindak sangat berbeda dalam suatu jaringan. Modal sosial yang 'mengikat', meskipun pada awalnya diperlukan untuk menyatukan orang (diasumsikan bahwa pelaku tunggal akan memiliki kesulitan dalam mempengaruhi perubahan) dalam keadaan tertentu dapat menghambat inovasi oleh (i) memotong aktor dari informasi yang dibutuhkan; (ii) memaksakan norma sosial yang menghambat inovasi; dan (iii) menolak penerimaan 'orang lain' dari luar komunitas. Namun, ikatan modal sosial mengarah ke tingkat kepercayaan yang lebih besar, yang diyakini banyak ahlI adalah pelumas penting untuk efektif hubungan sosial (Leonard \& Onyx, 2004). Modal sosial terikat dapat memainkan peran positif atau negatif. Modal sosial penghubung di sisi lain, memungkinkan para aktor untuk mengakses informasi luar dan mengatasi norma-norma 
sosial dengan dukungan dari luar jaringan lokal. Meskipun terlalu banyak pengaruh dari luar kelompok dapat mengganggu dalam kasus-kasus di mana 'orang luar' secara budaya tidak sensitif terhadap komunitas setempat, dalam kasus seperti itu ikatan penghubung dapat dibiarkan tersembunyi, membutuhkan sedikit perawatan sampai akhirnya diperlukan. Meskipun modal sosial penghubung mungkin tidak berfungsi dengan baik sendirian, sangat penting untuk proses perubahan dan lebih kritis terhadap kemampuan komunitas lokal untuk mendiversifikasi basis ekonominya. Dengan adanya dua bentuk modal sosial yang berbeda ini, jumlah modal sosial yang tipis kemungkinan tidak akan menjadi indikator yang baik tentang seberapa baik suatu komunitas dapat terlibat dalam masalah. Untuk memiliki gagasan tentang kemampuan ini, kita harus beralih ke indikator yang berbeda: agen perubahan.

\section{HASIL DAN PEMBAHASAN}

\section{Agen Perubahan}

Volume modal sosial yang dimiliki oleh agen yang diberikan tergantung pada ukuran koneksi jaringan yang ia dapat secara efektif dimobilisasi dan pada volume modal (ekonomi, budaya atau simbolik) yang dimiliki dalam haknya sendiri oleh masing-masing orang yang kepadanya ia terhubung (Bordieu, 1986). Dengan demikian, diskriminasi yang tidak memadai antara berbagai cara modal sosial bermain dalam satu komunitas, dan kurangnya perhatian terhadap struktur jaringan dan kemampuan untuk mengakses sumber daya di luar, hilangnya dinamika sosial dari hubungan komunitas. Kami percaya bahwa kebijakan pemerintah harus memahami interaksi dinamis ini karena tindakan mereka dapat memfasilitasi dan menghambat pembentukan jaringan, kecuali ditargetkan pada tingkat yang paling efektif agen perubahan dan aktor kunci yang menjembatani lintas jaringan.

Adalah keyakinan kami bahwa para pemikir dalam bidang pengembangan masyarakat perlu mengalihkan fokus mereka dari modal sosial. Apakah jaringan aktor dapat memanfaatkan modal sosial yang 'baik' dan mengatasi kendala modal sosial 'buruk' tergantung pada tingkat keagenan yang dimiliki aktor, dan tingkat 'keterbukaan' yang dimiliki kelompok terhadap 'orang luar'. Kualitas-kualitas ini, agen perubahan, modal sosial dan keterbukaan, secara dinamis saling terkait dan hidup bersama. Agen perubahan adalah indikator utama kemampuan kelompok untuk merespons dan mengidentifikasi solusi aktif untuk tantangan pembangunan berkelanjutan.

Ada beberapa definisi agen perubahan yang digunakan. Harvey (2002) mendefinisikan agen perubahan sebagai 'kapasitas orang untuk mengubah keadaan yang ada 
saat ini'. Definisi lain termasuk 'kapasitas individu untuk merencanakan dan memulai tindakan' (Onyx \& Bullen, 2000), dan kemampuan untuk merespons peristiwa di luar lingkup pengaruh langsung seseorang untuk menghasilkan efek yang diinginkan. Ini adalah kausalitas dan proses yang disengaja yang membawa keadaan baru yang tidak akan terjadi sebaliknya (Bhaskar, 1994).

Jika modal sosial digunakan, harus ada agen perubahan. Agen perubahan diperlukan bagi warga negara untuk dapat beradaptasi dengan lingkungan sosial budaya mereka, dan yang lebih penting untuk merespons dan mengahadapi tragedi dan krisis. Ini mendorong tindakan sosial yang memungkinkan warga negara untuk memperoleh hak dan sumber daya (Horvath, 1998). Agen perubahan adalah kekuatan di balik aksi sosial, dan para pelaku harus sadar bahwa mereka memiliki agen perubahan. Kita harus percaya bahwa perubahan itu mungkin, yang menciptakan proses pemberdayaan dan agen perubahan (Horvath, 1998; Bandura, 2000). Tidak mungkin ada agen tanpa kekuatan (Dietz \& Burns, 1992), akses ke informasi kritis, modal intelektual yang beragam, dan dalam jangka panjang kebijaksanaan (Dale, 2004).

Dietz dan Burns menghadirkan serangkaian sifat agen perubahan yang penting. Untuk memiliki hak pilihan, tindakan harus disengaja, agen harus memiliki kemampuan untuk membuat pilihan; misalnya, peluang untuk menjadi kreatif, dan mereka harus dapat memantau efek agen perubahan mereka (Dietz \& Burns, 1992). Properti terakhir ini sangat penting untuk isu-isu seperti masalah lingkungan di mana pemantauan jangka panjang diperlukan. Selain itu, kami percaya bahwa hak pilihan ditingkatkan ketika orang merasa mereka dapat mempengaruhi proses, bahwa suara mereka didengar, dan bahwa mereka dapat membuat perbedaan (Dale, 2005).

Agen perubahan jauh lebih dari komponen modal sosial, seperti yang disarankan oleh Onyx dan Bullen (2000). Dalam penelitian Krishna yang melibatkan desa-desa di India, tercatat bahwa jumlah modal sosial yang ada tidak ada hubungannya dengan hasil proyek pembangunan. Modal sosial tidak mengarah pada pencapaian kinerja pembangunan tinggi: agen juga diperlukan (Krishna, 2001). Desa dengan modal sosial yang kecil masih mencapai hasil yang baik jika agen perubahan mereka kuat. Selain itu, ia menemukan sedikit korelasi antara modal sosial dan tingkat agen perubahan (Krishna, 2001). Menurut Krishna, modal sosial adalah potensi, agen perubahan mengaktifkannya.

Keterikatan intim antara agen perubahan dan modal sosial menunjukkan jalan tengah dalam perdebatan yang sedang berlangsung tentang apakah individu menciptakan masyarakat 
atau apakah masyarakat menciptakan individu. (Sibeon, 1999) Manusia adalah produk dari lingkungan, tetapi juga penghasil lingkungan (Bandura, 2000). Seperti banyak konsep kompleks, struktur sosial dan agen perubahan berkembang bersama (Musolf, 2003). Ini adalah co-evolusi dan interaksi dinamis modal sosial, agen perubahan dan keterbukaan yang harus dieksplorasi lebih lanjut. Lebih jauh, jika struktur dan agen perubahan sosial adalah coevolusioner, maka mungkin saja keterikatan dan penghubung modal sosial mungkin bersifat rekursif, tergantung pada sifat masalah dan konteks sosiopolitik.

\section{Agen perubahan Pengukur dan Pendorong}

Dapat diperdebatkan apakah dan bagaimana modal sosial dapat dibangun (Krishna, 2001). Agen perubahan, bagaimanapun, adalah pintu belakang; seseorang dapat mendorong agen perubahan dan lebih baik menggunakan modal sosial yang ada. Lalu bagaimana, bisakah kita pertama-tama, mengukur, kedua, mendorong agen perubahan dan ketiga, menentukan apakah kebijakan pemerintah dapat meningkatkan agen perubahan di tingkat masyarakat?.

Ada beberapa batasan untuk agen perubahan: keterbatasan teknologi untuk tindakan yang mungkin, perbedaan dalam skala umpan balik waktu yang mengaburkan kemampuan kita untuk mengukur efek dari tindakan kita, struktur sosial membatasi pilihan kita yang mungkin, opsi kita mungkin akan disetujui oleh aktor yang lebih kuat (Dietz \& Burns, 1992). Keterbatasan pertama ini bukanlah sesuatu yang dapat diatasi oleh aktor individu, tetapi tiga sisanya mungkin semua dapat diatasi jika pengaturan yang tepat dari ikatan penghubung sudah ada. Kami tidak bermaksud mengatakan bahwa yang satu memiliki kelebihan intrinsik atas yang lain, tetapi bahwa yang terakhir mungkin lebih efektif dalam meningkatkan akses ke bentuk modal lain yang diperlukan untuk masyarakat. Mungkin juga ada unsur-unsur jaringan yang lebih tertutup, tingkah laku dengan modal ikatan yang sangat kuat, sehingga konsep keterbukaan terhadap orang lain dan khususnya, modal intelektual baru mungkin penting untuk pengembangan masyarakat yang berkelanjutan. Karena pembangunan berkelanjutan sering mengatasi masalah dengan lingkup global, pengelolaan masalah seperti itu di tingkat lokal mungkin memerlukan tindakan yang dikembangkan dalam konteks sosial yang sangat berbeda. Sikap 'kami tidak melakukannya di sini ' dapat menghentikan transfer pengetahuan yang penting ini.

Data dari bekas Jerman Timur mendukung argumen bahwa ikatan penghubung diperlukan untuk menciptakan agen perubahan dan dengan demikian memobilisasi modal 
sosial ke dalam aksi politik. Karena bahaya berbicara selama era komunis, orang cenderung menghindari berinteraksi dengan mereka yang tidak mereka kenal dengan baik. Akibatnya, ikatan pernikahan dihindari. Namun jaringan hubungan ikatan yang sangat erat terbentuk (Volker \& Flap, 2001). Struktur ini meninggalkan masyarakat dengan apa yang tampak sebagai modal sosial yang berlimpah, tetapi dengan kemampuan yang sangat buruk untuk menyelesaikan masalah sosial yang rumit yang membentang lintas yurisdiksi. Setelah Tembok Berlin runtuh, jejaring sosial yang sangat tertutup ini terbukti tidak memadai untuk mengatasi perubahan besar yang terjadi, dan komunitas Jerman Timur terbukti jauh kurang adaptif terhadap Barat (Volker \& Flap, 2001).

Bukan hanya kurangnya ikatan penghubung yang dapat menghambat hak pilihan; hubungan ikatan yang terikat terlalu banyak dapat memiliki efek yang sama. Kemudahan menggunakan hubungan ikatan yang terikat yang mapan dapat membuat kita tidak membuat ikatan baru (Gargiulo \& Benassi, 2000), mencegah perubahan. Kurangnya ikatan tidak langsung merangkum seseorang (Granovetter, 1973), memotong aliran informasi. Dan dalam hal adat istiadat yang terlalu ketat, modal ikatan dapat menahan perubahan dan menghambat modal penghubung (Rydin \& Holman, 2004). Untuk alasan ini Burt (1992) berpendapat bahwa jaringan seseorang membutuhkan 'lubang struktural' untuk memungkinkan perubahan dan penataan kembali, dan kami berpendapat, untuk keragaman kritis terjadi melalui keterbukaan kepada 'orang lain'.

Dalam hal pengembangan kebijakan strategis dan fasilitasi sosial, penelitian ini menunjukkan bahwa seseorang dapat mendorong agen perubahan dengan merangsang beragam campuran ikatan yang terikat dan ikatan penghubung, mungkin dengan menyediakan sumber informasi baru dan menciptakan hubungan antara berbagai kelompok. Seseorang juga dapat memfasilitasi hubungan vertikal ke berbagai tingkat pemerintahan. Namun sama pentingnya adalah untuk mendorong pengurangan homofili, terutama di masyarakat yang semakin majemuk dan beragam.

Homofili mengacu pada kecenderungan kita untuk berkelompok dengan orang yang sama. Dalam kelompok sosial kita sering melihat homofili usia, ras, kelas, agama, pendidikan dan pekerjaan (McPherson, dkk., 2001). Homofili, 'membatasi dunia orang dengan cara yang memiliki implikasi kuat untuk informasi yang mereka terima (dan menerima), sikap yang mereka bentuk, dan interaksi yang mereka alami (McPherson, dkk. 2001). Akibatnya, kelompok homofili akan sangat terikat dan tertutup dengan dunia luar, dan tidak mungkin memiliki ikatan yang diperlukan untuk menggunakan modal sosial apa yang tersedia di luar 
kelompok mereka. Dalam suatu krisis, kita lebih mungkin untuk memutuskan hubungan yang tidak homogen (McPherson, dkk., 2001), menjadikannya lebih buruk, sehingga salah satu tugas seorang fasilitator dalam kelompok masyarakat mungkin untuk mendorong pemeliharaan dan penanaman ikatan penghubung. Juga, suatu kelompok homofil kemungkinan besar akan terganggu oleh informasi dari luar karena mereka tidak terbiasa memasukkan informasi dan sumber daya dari ikatan penghubung. Keseimbangan yang dinamis dari obligasi dan modal penghubung mengurangi homofili dan mengurangi efek negatif homofili, menciptakan kelompok yang lebih tangguh.

\section{KESIMPULAN}

Penelitian komunitas menunjukkan bahwa komunitas-komunitas tersebut, khususnya, sumber daya ekonomi tunggal, yang lebih terbuka terhadap orang luar lebih tangguh dalam tanggapan mereka terhadap runtuhnya sumber daya ekonomi tunggal mereka (Connor, 2004; Dale \& Onyx, 2005). Selain itu, program komunitas yang menargetkan anak usia dini juga menggambarkan bagaimana praktisi dapat mempromosikan akses ke sumber daya yang berbeda oleh keluarga, dukungan sosial dan pengembangan jaringan komunitas yang dapat membantu mengatasi kemiskinan anak. Jika praktisi kebijakan tertarik untuk memfasilitasi tanggapan masyarakat terhadap kekuatan pasar lokal dan global, maka mereka perlu menyadari interkoneksi dinamis antara agen perubahan, modal sosial dan pembentukan jaringan. Lebih penting lagi, intervensi mereka dapat menghancurkan dan membangun modal sosial yang ada, dan itu adalah pendapat kami bahwa peran mereka yang paling efektif adalah untuk meningkatkan akses ke modal yang beragam, khususnya, sumber daya manusia, dengan meningkatkan ikatan hubungan, baik secara horisontal maupun vertikal. Ini membuat perbedaan antara individu dan komunitas dari 'mendapatkan' menjadi 'maju' (referensi). Selain tingkat intervensi, waktu intervensi kebijakan dalam pembentukan jaringan juga sangat penting, dan diperlukan lebih banyak penelitian di bidang kritis ini. Penelitian lebih lanjut juga diperlukan sehubungan dengan peran homofili dalam kelompok pembangunan berkelanjutan masyarakat.

Meskipun modal sosial merupakan komponen penting dari proses pemberdayaan yang dibutuhkan untuk mengatasi masalah seperti pembangunan berkelanjutan masyarakat, tidak dapat diasumsikan bahwa jumlah modal sosial yang ada akan berkorelasi langsung dengan hasil dari proses penyelesaian masalah yang melibatkan pembentukan jaringan. Agar prakarsa pembangunan berkelanjutan masyarakat berhasil, kelompok aktor yang terlibat 
harus memiliki agen perubahan di tingkat individu dan kelompok. Meskipun modal sosial merupakan komponen yang diperlukan dari agen perubahan itu, ia harus berupa suatu bentuk yang menciptakan dan bukannya menghambat agen perubahan. Secara khusus, modal sosial yang terdiri dari hubungan ikatan yang terikat cenderung menghambat inovasi dan mencegah perubahan struktural yang diperlukan untuk mencapai tujuan. Suara-suara yang tidak senang kemungkinan akan tertahan; agen individu hilang. Gabungan ikatan penghubung dan ikatan yang terikat meningkatkan agen perubahan karena ikatan penghubung memberikan aktor akses ke kelompok di luar kelompok lokal dan ikatan yang terikat memberikan kepercayaan. Ikatan prnghubung memiliki nilai dalam kemampuan mereka untuk menghubungkan para pelaku secara horizontal dengan kelompok-kelompok lain untuk berbagi informasi dan membangun basis sumber daya yang lebih besar, dan mereka menghubungkan para pelaku secara vertikal dengan para pembuat keputusan. Dengan demikian, ikatan penghubung sangat penting bagi aktor dan agen kelompok. Ikatan yang terikat dapat menghambat perubahan, dan adaptasi adalah kunci untuk mempertahankan nilai modal sosial (Gargiulo \& Benassi, 2000). Dengan demikian untuk mengoptimalkan agen kelompok untuk menggunakan modal sosial yang ada, ikatan penghubung harus didorong dan ikatan yang terikat dijaga seminimal mungkin untuk mendorong koneksi antar jaringan dan meningkatkan akses ke sumber daya luar. Selain itu, mungkin saja jaringan berkembang dalam hal bentuk-bentuk modal yang berbeda ini yang mengikat, dan menghubungkan dan lebih banyak penelitian perlu dilakukan di bidang ini.

\section{DAFTAR PURSTAKA}

Bandura, A. (2000) Exercise of human agency through collective efficacy, Current Directions in Psycho-logical Science, 9(3), pp. 75 - 78.

Bhaskar, R. (1994) Plato, Etc. The Problems of Philosophy and Their Resolution (New York, Verso).

Borgatti, S. \& Foster, P. (2003) The network paradigm in organisational research: a review and typology, Journal of Management, 29(6), pp. 991- 1013.

Bourdieu, P. (1986) The Forms of Capital, Handbook of Theory and Research for the Sociology of Education (New York, Greenwood Press).

Brundtland, G. (1987) Our Common Future: World Commission on Environment and Development (New York, Oxford University Press).

Burt, R. (1992) Structural Holes: the social structure of competition (Cambridge, Harvard University Press). 
Connor, R. (2004) Single industry towns and mine closure: what really matters. Thesis, Royal Roads University, Canada.

Dale, A. (2001) At the Edge. Sustainable Development in the Twenty-first Century (Vancouver, UBC Press).

Dale, A. (2004) Keynote speech to the New Zealand/Australian International Third Sector Conference. Brisbane, November 27.

Dale, A. (2005) Social capital and sustainable community development: is there a relationship?, in: A. Dale \& J. A. Onyx (Eds), Dynamic Balance: social capital and sustainable community development (Vancouver, UBC Press).

Dale, A. \& Onyx, J. (2005) A Dynamic Balance. Social Capital and Sustainable Community Development (Vancouver, UBC Press).

Dietz, T. \& Burns, T. (1992) Human agency and the evolutionary dynamics of culture, Acta Sociologica, 35, pp. 187-200.

Fine, B. (1999) The development state is dead: long live social capital?, Development and Change, 30, pp. $1-19$.

Fukuyama, F. (1999) The Great Disruption: human nature and the reconstitution of social order (New York, Free Press).

Gargiulo, M. \& Benassi, M. (2000) Trapped in your own net? Network cohesion, structural holes, and the adaptation of social capital, Organization Science, 11(2), pp. $183-196$.

Granovetter, M. (1973) The strength of weak ties, The American Journal of Sociology, 78(6), pp. $1360-1380$.

Harvey, D. (2002) Agency and community: a critical realist paradigm, Journal for the Theory of Social Behavior, 32(2), pp. 163-194.

Horvath, P. (1998) Agency and social adaptation, Applied Behavioral Science Review, 6(2), pp. 137-154.

Krishna, A. (2001) Moving from the stock of social capital to the flow of benefits: the role of agency, World Development, 29(6), pp. 925-943.

Leonard, R. \& Onyx, J. (2004) Social Capital and Community Building: spinning straw into gold (London, Janus Publishing Company).

McPherson, M., Smith-Lovin, L. \& Cook, J. (2001) Birds of a Feather: homophily in social networks, Annual Review of Sociology, 27, pp. 415-444.

Musolf, G. (2003) Social structure, human agency, and social policy, International Journal of Sociology and Social Policy, 23(6/7), pp. 1- 12.

Narayan, D. (1999) Bonds and Bridges: social capital and poverty (Washington, DC, World Bank). Onyx, J. \& Bullen, P. (2000) Measuring social capital in five communities, The Journal of Applied Behavioral Science, 36(1), pp. 23-42.

Portes, A. (1998) Social capital: its origins and applications in modern sociology, Annual Review of Sociology, 24, pp. 1-24.

Putnam, R. (2000) Bowling alone: the collapse and revival of American community (New York, Simon \& Schuster). 
Robinson, J. B. \& Tinker, J. (1997) Reconciling ecological, economic and social imperatives: a new conceptual framework, in: T. Schrecker (Ed.) Surviving Globalism: social and environmental dimensions (London, Macmillan).

Ruef, M. (2002) Strong ties, weak ties and islands: structural and cultural preictors of organisational innovation, Industrial and Corporate Change, 11(3), pp. 427-449.

Rydin, Y. \& Holman, N. (2004) Re-evaluating the contribution of social capital in achieving sustainable development, Local Environment, 9(2), pp. 117-133.

Sibeon, R. (1999) Agency, structure and social chance as cross-disciplinary concepts, Politics, 19(3), pp. $117-133$.

Volker, B. \& Flap, H. (2001) Weak ties as a liability: the case of East Germany, Rationality and Society, 13(4), pp. 397- 428.

Wilson, P. (1997). Building Social Capital: a learning agenda for the twenty first century, Urban Studies, 34(5/6), pp. 745 - 760.

Woolcock, M. (2001). The place of social capital in understanding social and economic outcomes, Canadian Journal of Policy Research, 2(1), pp. 11 - 17. 